DE DE GRUYTER OPEN
Journal of Intercultural Management Vol. 5, No. 3, September 2013, pp. 103-118

DOI 10.2478/joim-2013-0022

Michał Chmielecki

University of Social Sciences Lodz, Poland

\title{
Conceptual negotiation metaphors across cultures - research findings from Poland, China, The United States and Great Britain
}

\begin{abstract}
Recent years have seen an explosion of interest in the cultural dimensions of conflict resolution. Books, numerous studies, and courses have offered perspectives on the nature of culture and its complex relationship to the transformation of conflict. This article focuses on metaphors concerning negotiations across cultures. The study attempts to contribute knowledge in the field of cross-cultural studies on language and culture, especially with regards to negotiation metaphors. The article attempts to answer a question how does the usage of metaphors for the process of negotiation differ across cultures.
\end{abstract}

Key Word Topics: Metaphor; Culture, Negotiation; Conflict resolution, Cognition; Communications

\section{Introduction}

Studies, such as the famous work of Lakoff and Johnson [1980] have encouraged interest in metaphor. Their findings have led to more thorough examination of the subject in the years since the publication of their now famous Metaphors We Live By. Numerous scholars still point out that inadequate attention is being directed towards the examination of metaphor [Corradi Fiumara, 1995]. There is a need to study the linkage of metaphor with culture, and with particular domains. In supporting earlier studies by Borden [1982], Schaff [1973] and Galtung and Nishimura [1983], scholars Kuroda and Suzuki [1989] reiterated the salience of approaching cross cultural studies by focusing on language. In this view, language provides an important glimpse into local cultures, and as metaphor is ever-present in language, it exhibits a great potentiality for mirroring the culture. 
Corradi Fiumara [1995] believes that culture can best be communicated through metaphorical language, as "reliance on the literalness of cultural concepts may...conceal the danger of devaluing ... inner experiences..." [p. 2]. Metaphor is credited with passing cultural traditions from one generation to another and is recognized as a means, repository and agent for conditioning cultures.

Culture's impact on business and negotiations is immense. International business requires people to communicate more effectively across cultural and national boundaries. Managers in order to avoid failures need to approach negotiations from the more culturally competent point of view. For the past few decades scholars have explored the ways in which culture influences values, communication styles, and business practices. Today there is a great recognition among scholars and specialists that cultural differences affect all facets of international business. In this divergent and constantly changing environment negotiation is key area in which managers need to improve their expertise, [Loewenstein, Thomson, 2000] especially in intercultural aspects. Even those who never leave their home office have to interact effectively with people from varied backgrounds [Davison, Ward, 1999].

Metaphors become invisible through habitual use and processes that institutionalize the story behind the metaphor. However, they tell a lot about the attitude of the other side. That is why becoming culturally competent requires from negotiators also a deep understanding of metaphors used in the process of conflict resolution. Metaphors pervade the practice of negotiation and related dispute resolution processes and their use varies across cultures.

\section{Metaphor}

The importance of language and culture in management rests on the view that semantic distinctions reflect different interpretations of reality and normative modes of behavior. Words and especially metaphors are not just interchangeable labels denoting some given, immutable feature of the world but keys opening the door onto different configurations of the world. Metaphors are essential in human communication. They have been used and valued since antiquity. Aristotle himself once commented that "the greatest thing, by far, is to be a master of metaphor. It is the one thing that cannot be learnt; and it is also a sign of genius..." [as cited in Kittay, 1989, p. 1].

They are a key to understanding not only frames and unconscious thinking [Lakoff, Johnson, 1999], but also "regimes of truth" as well as intentions and evaluations [Charteris-Black, 2004]. Metaphors shed light on underlying meanings promising the possibility that negotiators can find out more about what is proposed and wanted and why. They can promote empathetic connection and are a good way to relate to opposing views. Metaphor could 
be used to shift attention and emphasis. Conceptual metaphors may account for the cognitive and social realities that negotiations are intended to address. When thinking about complicated problems and abstract ideas metaphors are invaluable [Kövecses, 2002]. Most negotiations are quite complex and to describe them negotiators use various metaphors. Metaphors can provide clues to how a negotiator might view the business negotiation.

Currently, there is no single theory that could possibly account for the full origin, evolution and social significance of metaphor. The range of theories currently in vogue are often contradictory. Some theories suggest that metaphor is intrinsic in us, some state that they have developed over time and, thus, are not inborn. The study of metaphor is marked by numerous debates, some of which are still present today. Among these include questions about the dividing line that separates metaphorical from the literal language; the dispute between universally-valid metaphors and culture-specific metaphors; and even questions about the distinction between metaphor and metonymy.

\section{Negotiations}

"Negotiation" derives from the Latin word negotiare meaning "to do business, trade, deal" and this original commercial sense is retained in many modern languages so that, for instance, negozio in Italian is a shop, negocios in Spanish is business. In contemporary English "negotiate" evokes a can-do, commercial world in which pragmatic individuals exchange views in order to arrive at a mutually satisfactory arrangement.

Many scholars would date rigorous research in the field of negotiation back to von Neumann and Morgenstern's [Von Neumann, Morgenstern, 1947] classic work on games and economic behavior. From that point many various definitions and approaches were coined. Negotiating can be viewed as coordination in an environment of diverse interests and conflicts [Ahdrich, 2006]. It can be portrayed as a management process of the interrelationship among interests, rights, and power between or among parties. Negotiation refers to a process in which individuals work together to formulate agreements about the issues in dispute. This process assumes that the parties are willing to communicate and to generate offers and counter-offers. Agreement occurs if and only if the offers made are accepted by both of the parties. Regardless of definition, negotiation involves several key components including two or more parties to a negotiation, their interests, their alternatives, the process and the negotiated outcomes.

It's worth stressing that negotiations are the subject of cross-cultural research in cross-cultural management. Intercultural management, as a field of knowledge, provides guidance that can be useful in business practices and enable efficient collaboration between people from different cultures. 
Intercultural management deals with the analysis of different types of crosscultural interactions for example: organizational culture, human resource management, operations and leadership teams multicultural development of cultural competence, expatriate issues, knowledge management, cross-cultural communication, cross-cultural conflict resolution including cross-cultural negotiations.

\section{Culture}

The belief that a nation possesses certain collective mental characteristics isn't a new concept. In 98 CE Tacitus described the character of ancient German tribes. In the $14^{\text {th }}$ century the great Muslim scholar Ibn Khaldûn described differences between mentalities of nomads and sedentary peoples [Hofstede, McRae, 2004]. Later in the 18th century, many renowned philosophers like Hume or Kant explored the questions of "national character". A lot of progress was done after World War II when the U.S. government asked anthropologists to help understand the way their enemy nations thought.

The role of culture in the world of business has been the subject of various research for at least twenty-five years. Researchers have studied the influence or the impact of national cultures on organizational behavior and the way managers from different cultural backgrounds interact with one another [Adler, 2002].

Cultures is complex and poses many problems of definition and interpretation [Sułkowski, 2009]. One of the most commonly used definitions of culture, being not a complex one at the same time, in the literature on culture, negotiations and business in general has been provided by Geert Hofstede, who was the author of the first major empirical multi-country study of consequences that culture has for the field of management. Hofstede defines culture as "the collective programming of the mind which distinguishes the members of one human group from another" [Hofstede, 2003].

Culture colours everything we see. It is a set of lenses through which all parties see conflict. Culture is also the medium in which behavioural patterns and values grow and are passed on one generation to the next. It is impossible to leave the cultural lenses at the door to a process. Without perspective and experiences through which we interpret and intuit the way forward, it would be impossible to transform conflicts. Cultural legacy gives people a range of behaviours from which to choose; it gives people a "common sense" of conflict and how to approach it.

Culture is always relevant. If we define culture broadly, that is, including many types and levels of difference, all conflicts are in the end intercultural. This comprehensive definition has the benefit of admitting culture as an element of every conflict analysis, even at the cost of an over-emphasis on cultural factors. 


\section{Understanding the role of culture in negotiations}

It's obvious that different cultural systems produce different negotiating styles and the effects of cross cultural differences on international negotiation are widely acknowledged. There is a substantial empirical evidence that negotiating tendencies differ by culture [Adair, Brett, Okumura, 2001]. These styles are shaped by each nation's culture, history and other factors. Negotiators experience not only differences in language or dress code, but also in different perception of the world definition of business goals and motivation.

Culture influences negotiation in many ways. Firstly through its effects on communications and through their conceptualizations of the process, then through the goals negotiators aim, the means they use, and the expectations they hold of the other side's behavior. Moreover, culture affects the range of strategies and tactics that negotiators develop. In international negotiations people bring to the negotiating table their beliefs, values and expectations. Very often they are unconscious of them. According to these values they interpret, present, judge and communicate. Cultural factors usually complicate and prolong negotiations. However, when properly managed they can lead to increased mutual gains.

All conflicts involve interpersonal interactions that occur in the context of cultures. It must be stressed that the exact influence of culture will differ from person to person as no two individuals from the same country, region, religion, socio-economic class or gender will exhibit the same patterns of cultural behaviours and attitudes.

Culture shapes not only the possibilities for resolution or transformation, but also the naming, interpretation, enactment and course of conflicts. A satisfactory response to conflict in cross-cultural setting requires a sophisticated understanding of culture, and quite an extensive experience across borders.

Lewicki et al. [Lewicki, Saunders, Minton, Barry, 2006] indicate, despite that fact that practitioners and scientists use the word 'culture' differently, they are agreeable that this is the culture that is the vital aspect of international negotiations. Thus cultural differences may influence negotiations in a variety of ways on of them is definition of negotiations. Metaphors are a perfect tool to understand how particular cultures define and understand negotiations.

\section{Metaphor in negotiations - current state of knowledge}

Metaphors have always been present in business and economics [Gramm, 1996; McCloskey, 1995; Schneider, 2002; White, Herrera 2003]. According to Boers [2000] typical metaphorical themes in economics are: mechanisms and machines, animals, plants and gardening, health and fitness, fighting and warfare, ships and sailing, and sports. 
Many researchers as well as practitioners of management use metaphorical representations of organisations. Some researchers even go so far as to assert that all modelling of organisations uses an implicit metaphor. The role of metaphors within the theory of organisations is cognitive, theoretical and didactic. Metaphors allow us a better understanding of the organisations we are studying.

However, metaphors have long infiltrated the other aspects of business such as workplace conditions, bargaining and negotiation and marketing as well.

Goodwin [1996] documented the extensive use of metaphors in the characterization of services offered. Walters-York [1996], on the other hand, observed the occurrence of metaphors in the sphere of accounting. Metaphors have left a deep imprint in marketing and promotion. Numerous studies have attested to the strong impact of metaphor in furthering sales [Boozer, R., Wyld, D. \& J. Grant, 1992].

In the field of workplace performance, numerous researchers have indicated the potentials of metaphors in motivating employees to excel in the disposition of their functions. For instance Phillips [1998] found out that the employment of metaphors can reveal performance limitations, pressure and stress among employees. Studies by Öztel and Hinz [2001] supported the role of metaphors in organizational change.

It has been said that metaphorical language helps in problem definition, strategy formulation, organizational reforms and even the basic act of managing [Suchan, 1995].

Smith [2005] discussed the persistence of metaphors in one of business' primary preoccupations, namely negotiation. Early recognition of metaphors in the course of a deal can bring full awareness of the intentions and implied suggestions of the party sitting on the other side of the negotiation table. With the resultant knowledge of each other's positions, both parties can better explore other options and opportunities for mutual advantage or compromise.

Until now, conflict resolution specialists have dealt with metaphor in a limited way. Typically [26] they have named a metaphor source domain in general terms (e.g. sports) and then given anecdotal examples of language.

A dispute has been understood in metaphoric terms as a battle, a sport or game, and dispute resolution as cooking, commerce, or sometimes even dancing and gardening. Wilmot and Hocker [Wilmot, Hocker, 2001] discuss sixteen common metaphors that negotiators use to approach conflict or to form a perspective: war, struggle, explosions, court trial, force of nature, animal behavior, messiness, communications breakdown, games, heroic adventure, balancing, bargaining, a tide, a garden, a dance, or as quilt-making. Gelfand and McCusker [Gelfand, McCusker, 2002] cite some of these, enlarging games 
to include sports and adding theatre/cinema as a source domain. Haynes [1999] discusses war, competitive games, and journey metaphors.

Negotiation can be a game of poker in which players must hold the cards close to the chest. Negotiation can be viewed as football, where a "level playing field" is required; mediators are thus "umpires" or "referees.", or like basketball, where "timeouts" are sometimes taken, or like baseball where parties sometimes play "hardball" [Thornburg, 1995] [Archer, Cohen, 1998].

\section{Research methods and findings}

The article attempts to answer a question how does the usage of metaphors for the process of negotiation differ across cultures. The research was based on literature studies, IDI and CAWI (Fig. 1). IDIs were conducted from the beginning of May until the end of July 2012 and British sample was added from in July 2013. CAWIs were obtained in July and August 2013.

Figure 1. Research process.

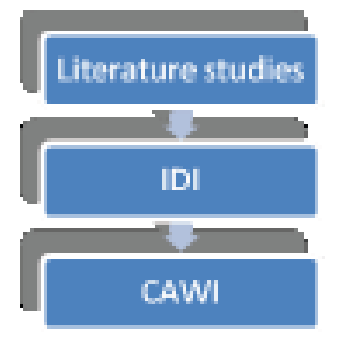

Source: own study.

The main hypothesis of this study is that negotiators from Poland would be more similar to US and British negotiators in defining and understanding negotiation process than to Chinese negotiators.

In the first part of the research process literature studies and IDI served as methods for identifying and defining metaphors for negotiations. 32 IDIs were conducted. 8 with representatives of American culture, 6 with representatives of Chinese culture and 8 with representatives of Polish culture and 9 with representatives of British culture (see Tab. 1).

Table 1. Demographic differences between respondents - IDI

\begin{tabular}{|l|l|l|l|l|}
\hline Country & Chinese & American & Polish & British \\
& & & & \\
\hline
\end{tabular}




\begin{tabular}{|l|l|l|l|l|l|l|l|l|}
\hline Sex & 4 & 2 female & 5 male & $\begin{array}{l}3 \\
\text { female }\end{array}$ & $\begin{array}{l}5 \\
\text { male }\end{array}$ & $\begin{array}{l}3 \\
\text { female }\end{array}$ & 5 male & 4 female \\
\hline Age -mean & 46 & 35 & 34 & 35 & 39 & 37 & 33 & 31 \\
\hline $\begin{array}{l}\text { Education: } \\
\text { Academic degree }\end{array}$ & 4 & 2 & 4 & 3 & 5 & 3 & 5 & 4 \\
\hline $\begin{array}{l}\text { Professional } \\
\text { experience in } \\
\text { conducting } \\
\text { business } \\
\text { negotiations in } \\
\text { years - mean }\end{array}$ & 15 & 9 & 11 & 13 & 17 & 13 & 8 & 6 \\
\hline
\end{tabular}

Source: Own study.

Metaphors used for the process of negotiation and their explanations are presented in table 2.

Table 2. Metaphors used for the process of negotiation and their explanations.

\begin{tabular}{|l|l|}
\hline Metaphor & Description \\
\hline War & $\begin{array}{l}\text { Negotiation is a process where you either "win or lose." In negotiation every move } \\
\text { is justified. The other side is suspicious of our motives. }\end{array}$ \\
\hline Marathon & Negotiations can be painful. They require time. Success needs time. \\
\hline Poker & $\begin{array}{l}\text { The other party will probably try to cheat us somehow. We have to be vigilant } \\
\text { about of the possibility of unethical tactics being employed against us. }\end{array}$ \\
\hline Climbing & $\begin{array}{l}\text { It's a risky process, that requires a lot of preparation. Sometimes you need } \\
\text { to resign at some level. There are many surprises waiting for you during the } \\
\text { process, that is why you never go alone and you have to rely on others. }\end{array}$ \\
\hline Journey & $\begin{array}{l}\text { In this domain, as the term denotes, negotiation process is made akin to that of } \\
\text { a journey, where there is a reference or starting point and a destination or end } \\
\text { point. On the way there are some 'twists and turns,' sometimes you come across } \\
\text { a "stumbling block' and you have to 'clear the way'. }\end{array}$ \\
\hline
\end{tabular}




\begin{tabular}{|l|l|}
\hline Cooking & $\begin{array}{l}\text { Both parties must cooperate and complete one another in order to achieve a } \\
\text { goal. }\end{array}$ \\
\hline Dance & $\begin{array}{l}\text { You must be engaged in it with all your soul. You need to move with grace and } \\
\text { flow with the melody line (the external negotiation environment you cannot } \\
\text { change). }\end{array}$ \\
\hline Sculpting & $\begin{array}{l}\text { Like sculptor you need to get rid of many unnecessary layers of information and } \\
\text { get to the core. }\end{array}$ \\
\hline Golf & $\begin{array}{l}\text { In golf you adhere to the rules, you display professional etiquette. From time to } \\
\text { time you have to take risks but all the time you have to maintain focus. Trust in } \\
\text { relationships is essential. Every shot completed gives you another opportunity } \\
\text { to make another one. Negotiators are not in a hurry to get to the end. When the } \\
\text { ball is in the hole, there are no more shots. Golf is often a game of luck. A bad } \\
\text { bounce here or a good bounce there can sometimes make all of the difference in } \\
\text { a round. }\end{array}$ \\
\hline $\begin{array}{l}\text { Football } \\
\text { (soccer) }\end{array}$ & $\begin{array}{l}\text { Metaphorical use of football serves to highlight the stresses of the long } \\
\text { negotiations, the highly conflictual confrontations and the strategy to extend } \\
\text { deadlines and buy time in the face of the inability to reach a satisfactory } \\
\text { agreement that would (temporarily) pacify the conflict. }\end{array}$ \\
\hline $\begin{array}{l}\text { Playing in } \\
\text { a band }\end{array}$ & $\begin{array}{l}\text { Understanding and open communication between parties is crucial. If you want } \\
\text { to focus attention on yourself too much you won't reach a goal. }\end{array}$ \\
\hline
\end{tabular}

Source: own study.

In the second part, a questionnaire was developed to explore how do respondents from different cultures view and understand the process of negotiation. In total, 261 respondents took part in the online survey. 74 from Poland, 51 from China, 75 from the USA and 61 from Great Britain.

Table 3. Demographic differences between respondents - CAWI

\begin{tabular}{|c|c|c|c|c|c|c|c|c|}
\hline & \multicolumn{2}{|c|}{ Poland } & \multicolumn{2}{|l|}{ China } & \multicolumn{2}{|l|}{ USA } & \multicolumn{2}{|c|}{ Great Britain } \\
\hline $\begin{array}{l}\text { Number of } \\
\text { respondents }\end{array}$ & 74 & & 51 & & 75 & & 61 & \\
\hline Sex & $\begin{array}{l}38 \\
\text { male }\end{array}$ & $\begin{array}{l}36 \\
\text { female }\end{array}$ & $\begin{array}{l}33 \\
\text { Male }\end{array}$ & $\begin{array}{l}18 \\
\text { female }\end{array}$ & $\begin{array}{c}42 \\
\text { male }\end{array}$ & $\begin{array}{l}33 \\
\text { female }\end{array}$ & $\begin{array}{l}33 \\
\text { male }\end{array}$ & $\begin{array}{l}28 \\
\text { female }\end{array}$ \\
\hline Age - mean & 44 & 43 & 45 & 39 & 39 & 36 & 37 & 36 \\
\hline $\begin{array}{l}\text { Education: } \\
\text { Academic } \\
\text { degree }\end{array}$ & 37 & 36 & 33 & 17 & 38 & 27 & 32 & 26 \\
\hline $\begin{array}{l}\text { Years of } \\
\text { professional } \\
\text { experience } \\
\text { in business } \\
\text { negotiations - } \\
\text { mean }\end{array}$ & 26 & 22 & 23 & 15 & 15 & 12 & 14 & 12 \\
\hline
\end{tabular}

Source: Own study. 
Respondents were asked to choose one metaphor that best describes the process of negotiation. Metaphors were selected for the questionnaire on the basis of previously conducted IDIs.

Table 4. Metaphors describing the process of negotiations.

\begin{tabular}{lllll}
\hline & Poland & China & USA & Great Britain \\
\hline War & $26 \%$ & $8 \%$ & $24 \%$ & $23 \%$ \\
Marathon & $7 \%$ & $20 \%$ & $9 \%$ & $8 \%$ \\
Poker & $35 \%$ & $10 \%$ & $19 \%$ & $10 \%$ \\
Climbing & $5 \%$ & $18 \%$ & $4 \%$ & $7 \%$ \\
Cooking & $4 \%$ & $6 \%$ & $3 \%$ & $3 \%$ \\
Dance & $3 \%$ & $8 \%$ & $3 \%$ & $3 \%$ \\
Sculpting & $0 \%$ & $4 \%$ & $1 \%$ & $0 \%$ \\
Journey & $5 \%$ & $16 \%$ & $8 \%$ & $10 \%$ \\
Golf & $7 \%$ & $0 \%$ & $16 \%$ & $15 \%$ \\
Footbal (soccer) & $4 \%$ & $4 \%$ & $7 \%$ & $18 \%$ \\
Plaing in a band & $4 \%$ & $8 \%$ & $7 \%$ & $3 \%$ \\
\hline
\end{tabular}

Source: Own study.

There were few more metaphors found during conducting literature studies but none of the respondents indicated them as relevant. Table 4 presents the results of the questionnaire.

Figure 2. Metaphors describing the process of negotiations.

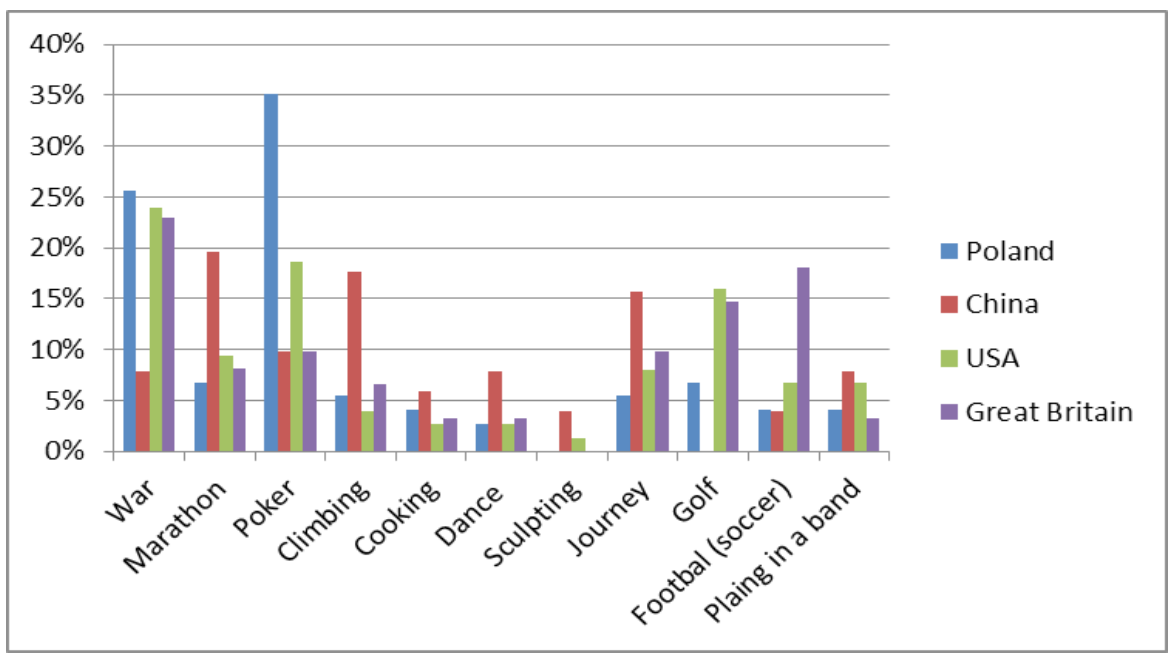

Source: Own study. 


\section{Discussion}

There is a universal model of the basic procedures of negotiation. However, this impressive consensus on the mechanics of negotiating conceals subtle, yet far-reaching differences in the way basic concepts and moves are interpreted, evaluated, and actualized.

It is clearly visible from the graph that the usage of metaphors for the process of negotiation differs across cultures. It is also visible that some metaphors such as war and sports metaphors are generally more accurate than art metaphors such as dance or sculpting in all of the cultures. The main hypothesis of this study is that negotiators form Poland would be more similar to US and British negotiators in defining and understanding negotiation process than to Chinese negotiators. It is visible that in terms of understanding and referring to the process of negotiation Polish respondents are closer to American and British respondents than to Chinese ones which proves the hypothesis.

The initial categorizations looks as follows: an American negotiator will try to control as much as possible. He is the battlefield commander, calling the shots and bringing the firepower of his intellect to bear on the opposing forces. Chinese negotiator likes to give the appearance of being able to endure any amount of pain to get to the point where he wants to be. Polish negotiator is a poker player, he expects to be cheated at some point, he is very distrustful. However, what do these approaches stem from?

Chinese culture by many researchers [Bond, Hwang, 1986, pp.213266] [Gabrenya, Latané, Wang, 1983, pp. 368-384] has been categorized as collectivistic. Collectivism is present in many aspects of the negotiations. Both the high degree of collectivism as well as long-term orientation [Hofstede, 2003] are characteristic for Chinese culture. They are a kind of mutual exchange warranty [Williams, Nussbaum, 2001]. The relationship is formed on mutual favours exchanged among the members of the group [Tan, Snell, 2002] [Walder, Li, Treiman, 2000]. Due to Confucianism they become the social norm. The Chinese treat each person differently depending on the relationship prevailing between them. Another important concept which is important here is "guanxi". Studies show that despite the fact that guanxi is culturally and historically "built" in the Chinese way of thinking and acting [Standird, Marshall, 2000] [Wong, Tam, 2000], this concept will change in the near future. Any attempt to do business arrangements without the establishment of an appropriate harmony will be considered rude. Trust and harmony are more important to the Chinese than any document. Until recently, China's property rights did not exist. Not surprisingly, they rely more on trust than rigid contractual arrangements. Another important element here is the concept of "chiku nailao" which translates into hard work and being diligent. Hard work, even in very 
difficult conditions is for the Chinese ideal of itself. Here where martial arts were born, masters achieved perfection after years of painstaking work and thousands of repetitions of blocks, strikes and kicks. How perseverance and diligence translates into negotiations? Certainly when it comes to preparing for negotiations the Chinese "do their homework" more diligently than their Western counterparts. The second thing is perseverance at the negotiating table. This is what the Chinese will be normal for a European can be a very exhausting experience. Demonstrating patience is a good sign "chiku nailao". Rarely does it happen that the Chinese accept the concessions in the early stages of the negotiations. In addition, they have a huge range of tactics, with an emphasis on the extension of the negotiation process and achieve better agreement. As in China the important role in shaping the contemporary values of Chinese was played by Confucianism, when it comes to the United States it was the set of characteristics of people who settled in the new territory. Colonizers rather quickly joined some of the Anglo-Saxon values of individualism with the lack of formal rules of communication and efficient use of time. Those emigrants who left Europe and came to America, already manifested their individualism through emigration. Besides, they believed in freedom, equality, self-improvement and accountability.

Americans tend to be very meticulous. Relatively quickly threaten to appear in court under threat of penalty. Americans impose a fast pace for conversations. This could pose a serious threat to the provider and can make the he would regret that he agreed to accept some of the wording in the contract given to him by a merchant from America. Are relatively persistent and in the case of failures do not give up. They are aggressive and, at all costs, they seek to win. Furthermore, they consider that every negotiations must result in a particular set. "For the competitive Americans who hate to lose, everything in life is a game you should win»[Kim, 2001, p. 40]. Americans are energetic, expansive and assertive. They are full of faith and optimism. Americans are willing to take risks. The innovation, change and progress are highly valued.

Because of the Polish history, i.e. partition of Poland, two world wars, communist era the country did not have proper conditions to develop international trade and that is why does not have a strong tradition in negotiations. It also explains the fact why Poles tend to be so distrustful about business partners. It is still common to use bribes, kick-backs, or other inducements in Polish business life. Family and friend bonds still play a key role in Polish business culture. When it comes to other elements of negotiations it is suggested that the approach towards the negotiation process itself is rather flexible than systematic or even at time chaotic. Preparation is still a problem among Polish negotiators and they do not attach too much importance to it. Time factor does not seem to be creating much pressure. 
In Great Britain there are three prevailing metaphors shaping how negotiation is conceived, two come from sports - football and golf, the third refers to war. The sporting metaphor emerges in such terms as "hole in one", "opening bid", "fair offer", "hold strong cards", "out of bounds", "rules of the game", "kick off", "moving the goalposts", and so on. This vocabulary reflects a tendency to think of negotiation as a sporting contest governed by set of rules. After a hard fought, but fair game, there is a result and the teams go home. This metaphor makes it difficult to conceive of a negotiation as a life or death confrontation between possibly unscrupulous opponents willing to try every (dirty) trick in the book, and not played by the Queensberry Rules. The British like to be part of a team and like the team to have a companionable atmosphere. Members of a team are expected to take an holistic interest in the negotiation process, rather than confining themselves to their allocated role only. The British place diplomacy firmly before directness and will try to avoid engendering negative emotions in meeting situations etc. and they can misinterpret direct speech as rudeness, aggression and arrogance. Those explain why they need and like rules. There is a proper way to act in most situations and the British are sticklers for adherence to protocol. On the other hand negotiation was often conceptualized as 'war'. hey come to the session armed with the facts, they are ready to shoot down your argument, there are casualties. There are many injuries and, as with most wars, a victor and a loser, or two losers.

Although the literature abounds with the benefits of metaphors in business, some scholars raised the alarm over the possible downsides of using figurative language. Smith [2005] warned of the dangers of the use of metaphors. According to him metaphors tend to highlight certain areas while covering others. Because of the fact that metaphors can reduce analysis of a complex phenomenon to a simple plane, it may cause a party to approve a proposal, while not being made aware of the total picture [Smith, 2005].

\section{Limitations}

It should be stressed once again that the survey was a pilot study, and the results cannot be generalized. The presented results serve as a starting point for further in-depth research in this area. It is recommended that in order to gain a fuller picture of the issues underlying the findings, both qualitative and quantitative research on a bigger scale should be undertaken.

\section{Conclusion}

Cross cultural differences can thwart negotiators' plans. It is therefore crucial that they incorporate a cross cultural competence and global thinking approach. With the growth of international business, negotiations have become 
more complex. Negotiation functions therefore become far more challenging. In addition to the usual professional skills, negotiators should expand their knowledge of world cultures, languages, customs, ways of conducting business. Cultural misunderstandings occur not only when difference is noticed and misinterpreted, but very often when a surface similarity (e.g. in etiquette) obscures significant difference that exist at the deep level. Perhaps treating each negotiation as unique is the key to success.

Cultural competence includes not only knowledge of history, language, verbal or non-verbal behavior, world-views or 'do's and don'ts' but also values, norms etc. Unfortunately, much of such cultural "knowledge" stems from stereotypes or certain simplifications. Too often people attach some positive or negative value and emotional color to them. "People from different countries see, interpret, and evaluate events differently, and consequently act upon them differently" [Adler, 2002, p. 77]. They also use different metaphors to describe the process of negotiation. It is important to understand it because many people spontaneously use metaphor to influence the conflict resolution process. They seem to recognize that metaphor can work quickly and naturally to change thinking about the process.

\section{Bibliography}

Ahdrich, R. B., The Strategy of Boilerplate, Michigan Law Review, Volume 108, Issue 5, 2006,

Adair, W.L., Brett, J.M. ,Okumura, T., Negotiation Behavior When Cultures Collide: The United States and Japan, Journal of Applied Psychology 80(3), 2001,

Adler, N. J., International dimensions of organizational behavior (4th ed.). Cincinnati, OH:Thomson/South-Western, 2002,

Archer, M., Cohen, R., Sidelined on the (Judicial) Bench: Sports Metaphors in Judicial Opinions, American Business Law Journal, 35, 1998,

Boers, Frank. (2000). Enhancing Metaphoric Awareness in Specialised Reading in English for Specific Purposes, volume 19, issue 2: 137-147

Bond, M. H., Hwang, K., K., The social psychology of the Chinese people, [in:] M. H. Bond (Ed.) The psychology of the Chinese people, New York, 1986,

Borden M. A. (1982). Implications of Language Studies for Human Nature. In T. W. Simon \& Scholes, R. J. (Eds.), Language, Mind, and Brain (pp. 129 - 143). Hillsdale, NJ: Lawrence Erlbaum Associates.

Boozer, R., Wyld, D. \& Grant, J. (1992). Using Metaphor to Create More Effective Sales Messages. Journal of Business \& Industrial Marketing , 7 (1).

Charteris-Black, J., Corpus approaches to critical metaphor analysis, Basingstoke: Palgrave Macmillan, 2004,

Corradi Fiumara, G., The Metaphoric Process: Connections Between Language and Life . London \& New York: Routledge, 1995 
Davison, S. C., Ward, K., Leading International Teams, London: McGraw-Hill, 1999,

Gabrenya, W.K, Latané, B., Wang Y., Social loafing in cross-cultural perspective: Chinese on Taiwan, Journal of Cross-Cultural Psychology, 14 (3), 1983,

Galtung J., \& Nishimura F. (1983). Structure, Culture and Languages: An Essay Comparing the Indo-European, Chinese and Japanese Languages. Social Science Information , 22(6), 895-925.

Gelfand, M. J., McCusker, C., Metaphor and the cultural construction of negotiation: A paradigm for theory and research [in:] M. Gannon, K. L. Newman (Eds.) Handbook of cross-cultural management, New York: Blackwell, 2002,

Goodwin, C. (September 1996). Moving the Drama Into the Factory: The Contribution of Metaphors to Services Research. European Journal of Marketing , 30 (9), 13 - 36.

Gramm, W. (1996). Economic Metaphors: Ideology, Rhetoric, and Theory. In Katz, A. \& J.S. Mio. (Eds.) Metaphor: Implications and Applications (pp. 147-170) Mahwah, NJ: Lawrence Erlbaum Associates.

Haynes, J., Metaphor and Mediation, published electronically at http://mediate.com/ articles/metaphor.cfm, 1999.

Hofstede, G., Culture's Consequences: Comparing Values, Behaviors, Institutions and Organizations Across Nations, London, 2003,

Hofstede G., McRae R.R., Personality and Culture, Revisited: Linking Traits and Dimensions of Culture, Cross-Cultural Research, Vol. 38 No. 1, 2004

Kim Y., Becoming Intercultural: An Integrative Theory of Communication and Cross-Cultural Adaptation, London: Sage, 2001.

Kittay, E. F. (1989). Metaphor: Its Cognitive Force and Linguistic Structure, Oxford: Clarendon Press.

Kövecses, Z., Metaphor: A Practical Introduction. Oxford: Oxford University Press, 2002

Kuroda, Y. \& Suzuki, T. (1989). Language and Attitude: A Study in Arabic, English, and Japanese on the Role of Language. In Crowell, D., Kobayashi, D. \& Topping, D. Thinking Across Cultures (pp. 147-161). Hillsdale, NJ: Lawrence Erlbaum Associates.

Lakoff, G. \& M. Johnson (1980). Metaphors We Live By . Chicago: Chicago University Press.

Lakoff, G., Johnson M., Philosophy In The Flesh: The Embodied Mind and Its Challenge to Western Thought. Basic Books, 1999

Lewicki, R., Saunders, D., Minton, J. and Barry, B. Negotiation. New York: McGraw-Hill Irwin, 2006.

Loewenstein, J., Thomson L., The challenge of learning, Negotiation journal, 16(4), 399408, 2000

McCloskey, D. (1995). Metaphors Economists Live By. Social Research, 62, (2), 215237.

Oztel and Hinz (2001). Changing organisations with metaphors, The learning Organization, Bradford, 8 (3), p. 153. 
Phillips, B. (1998). Energy and Performance: the Power of Metaphor. Career Development International , 3 (1), 18-22.

Schaff A. (1973). Language and Cognition . New York: McGraw-Hill.

Schneider, W. (2002, 9 February). Politics: Enron as Metaphor. National Journal

Smith, T. (2005). Metaphors for Navigating Negotiations. Negotiation Journal. 21 (3), 343-365.

Standird, S., Marshall, R.S., The transaction cost advantage of guanxi-based business practices. Journal of World Business, 35, 2000,

Suchan, J. (1995). The Influence of Organizational Metaphors on Writers' Communication Roles and Stylistic Choices. The Journal of Business Communication, $32(1)$

Sułkowski Ł., The problems of epistemology of corporate culture, "Journal of Intercultural Management", 2009.

Tan, D., Snell, R.S., The third eye: Exploring guanxi and relational morality in the workplace, Journal of Business Ethics, 41(4), 2002,

Thornburg, E., Metaphors Matter: How Images of Battle, Sports, and Sex Shape the Adversary System, Wisconsin Women's Law Journal, 10, 1995,

Von Neumann, J., Morgenstern, O., Theory of games and economic behavior (2nd Rev. ed.). Princeton, NJ:Princeton University Press, 1947,

Walters-York, L.M. (1996). Metaphor in Accounting Discourse. Accounting, Auditing \& Accountability Journal, 9 (5), 45 - 70.

Walder, A.G., Li, B., Treiman, D.J., Politics and life changes in a state socialist regime:Dual career paths into the urban Chinese elite, 1949 to 1996., American Sociological Review, 65, 2000,

White, M. \& H. Herrera. (2003). Metaphor and Ideology in the Press Coverage of Telecom Corporate Consolidations. In Dirven, R., Frank, R. \& Pütz, M. Cognitive Models in Language and Thought: Ideology, Metaphors and Meanings (pp. 277-323). Berlin \& New York: Mouton de Gruyter.

Wong, Y.H., Tam, J.H.L. Mapping relationships in China: Guanxi dynamic approach, Journal of Business and Industrial Marketing, 15, 2000,

Williams, A., Nussbaum, J.F., Intergenerational communication across the life span. Mahwah, NJ: Lawrence Erlbaum, 2001,

Wilmot, W., Hocker, J., Interpersonal conflict, (6th ed.). New York: McGraw-Hill Education, 2001. 